\title{
FAKTOR NIAT BERWIRAUSAHA PADA MAHASISWA FAKULTAS EKONOMI DI JAKARTA BARAT
}

\author{
Van-ni dan Andi Wijaya \\ Program Studi Manajemen Fakultas Ekonomi Universitas Tarumanagara, Jakarta \\ E-mail : van.115170036@stu.untar.ac.id
}

\begin{abstract}
The purpose of this study was to determine the effect of entrepreneurship education, financial support on the entrepreneurial attitudes and entrepreneurial intentions from economics faculty students at private universities in West Jakarta. This study uses the Judgment sampling method. Research respondents were collected from 100 private university students who were previously distributed through an online questionnaire. Data analysis using SEM-PLS. In the results of research, education and financial support have an effect on entrepreneurial attitudes for entrepreneurship. Entrepreneurial attitude has an effect on entrepreneurial intentions.
\end{abstract}

Keywords: Entrepreneur Education, Financial Support, Entrepreneurial Attitude, Entrepreneurial Intention.

Abstrak: Tujuan penelitian ini adalah mengetahui adanya pengaruh dari pendidikan kewirausahaan, dukungan finansial kepada sikap kewirausahaan dan niat berwirausaha dari mahasiswa dan mahasiswi fakultas ekonomi pada perguruan tinggi swasta di Jakarta barat. Penelitian menggunakan metode Judgement sampling. Responden penelitian terkumpul dari 100 mahasiswa perguruan tinggi swasta yang sebelumnya disebarkan melalui kuisioner Online. Analisis data menggunakan SEM-PLS. Pada hasil penelitian pendidikan dan dukungan finansial berpengaruh pada sikap kewirausahaan untuk berwirausaha. Sikap kewirausahaan berpengaruh pada niat kewirausahaan.

Keywords: Pendidikan Kewirausahaan, Dukungan Finansial, Sikap Kewirausahaan, Niat Kewirausahaan

\section{LATAR BELAKANG}

Berdasarkan Hasil Sensus 2020 oleh Badan Pusat Statistik, Indonesia memiliki memiliki populasi sebanyak 270,20 juta jiwa di tahun 2020. Namun disayangkan dengan populasi tersebut masih terdapat pengangguran yang menjadi salah satu masalah negara yang belum terselesaikan. Untuk menurunkan tingkat pengangguran pemerintah membuka lapangan dapat dengan berwirausaha. Selain membuka peluang lapangan kerja dalam jangka waktu yang dekat maupun jangka panjang, wirausaha juga dapat membawa pertumbuhan ekonomi pada sebuah negara (Acs et al., 2018).

Rasio kewirausahaan Indonesia berkisar 3,55 persen tergolong rendah. Dengan pertimbangan inovasi dapat mendorong individu karena lebih yakin dengan kemungkinan keberhasilan dari satu ide bisnis pada jasa ataupun produk dengan adanya tingkat inovasi pada industri (Monica dan Wijaya, 2021). Kesiapan seseorang memiliki kaitan dengan perilaku seseorang diperkuat dengan demokrasi politik, regulasi pemerintahan, keadaan keuangan modal kemampuan dan keinginan berwirausaha dan likuiditas pasar (Raza Muffatto dan Saeed, 2018). Niat tersebut dari pandangan seseorang dalam melihat karir wirausaha. Pandangan 
tersebut dapat berasal dari latar belakang individu, salah satunya pada pendidikan (Hisrich et al., 2017).

Tujuan dari penelitian ini adalah untuk mengetahui apakah adanya Pengaruh antara pendidikan kewirausahaan dan sikap kewirausahaan kepada niat kewirausahaan mahasiswa perguruan tinggi, Pengaruh antara dukungan finansial dan sikap kewirausahaan kepada niat kewirausahaan mahasiswa perguruan tinggi. Serta pengaruh sikap kewirausahaan kepada niat kewirausahaan mahasiswa perguruan tinggi. Penelitian merupakan perluas dari penelitian sebelumnya yang berasal dari Malaysia.

\section{KAJIAN TEORI}

Teori yang digunakan adalah Theory Planned Behavior (TPB). Theory Planned Behavior (TPB) yang dikemukakan oleh Ajzen (1985). Menurut Theory Planned Behavior (TPB) niat dapat memprediksi perilaku. Niat yang kuat bersamaan dengan perilaku yang terencana akan meningkatkan performanya Untuk memprediksi perilaku seseorang dapat diprediksi melalui tiga kunci yakni sikap, norma subyektif, dan persepsi kontrol perilaku (Ajzen, 1991). Kegiatan luar yang mendorong kompetensi pada kegiatan kewirausahaan memperkuat keterampilan individu. Pendidikan kewirausahaan melalui pembelajaran akan kewirausahaan kemungkinan memindahkan informasi dan pengetahuan kepada pelajar (Kim dan Park, 2019).

Sikap berwirausaha merupakan keinginan seseorang untuk menjadi wirausaha yang mendahului intensi berwirausaha, dan merupakan wujud niat seseorang untuk berperilaku dengan cara tertentu (Masango dan Lassalle, 2020). Sikap mengarah ke perilaku, dengan demikian memprediksi niat karenanya sikap merupakan prediktor yang penting pada niat kewirausahaan (Botsaris dan Vamvaka, 2016). Orientasi dari sikap kewirausahaan memberikan pengaruh pada niat seseorang (Hansfel dan Puspitowati, 2020). Dengan memiliki tingkat yang tinggi pula maka kewirausahaan dapat mendorong seseorang untuk berwirausaha (Do dan Dadvari, 2017).

Sikap memiliki hubungan dalam niat wirausaha. Sebab sikap dan penilaian yang memiliki bersifat evaluatif seorang individu kepada tindakan khususnya menjadi seorang wirausaha. Menurut Thompson (2009) Niat kewirausahaan adalah kepercayaan diri dari seseorang individu yang memiliki niat untuk menciptakan perusahaan baru atau aktivitas terkait dengan bisnis. Berdasarkan pada pembahasan sebelumnya maka peneliti memilih untuk meneliti variabel dependen yaitu sikap kewirusahaan dan niat kewirausahaan serta variabel independen pendidikan kewirausahaan dan dukungan finansial

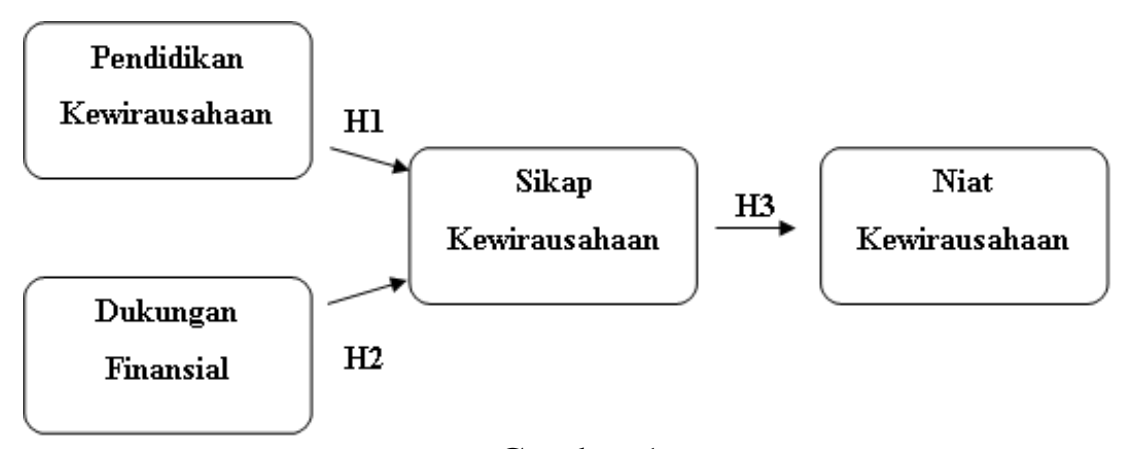

Gambar 1

Model Penelitian 
H1 : Adanya pengaruh positif signifikan pendidikan kewirausahaan kepada sikap kewirausahaan untuk berwirausaha.

$\mathrm{H} 2$ : Adanya pengaruh positif signifikan dukungan finansial kepada sikap kewirausahaan untuk berwirausaha.

H3 : Adanya pengaruh positif signifikan sikap kewirausahaan kepada niat kewirausahaan untuk berwirausaha.

\section{METODOLOGI}

Penelitian yang dilakukan dengan mengambil populasi dari para mahasiswa dan mahasiswi yang tengah menduduki perguruan tinggi swasta di Jakarta Barat. Sampel penelitian yakni Mahasiswa dan Mahasiswi fakultas ekonomi dari perguruan tinggi swasta yang telah mempelajari mata kuliah terkait dasar-dasar kewirausahaan atau sejenisnya. Dalam pengambilan sampel, penelitian ini menggunakan teknik Non-Probability Sampling.

Penelitian ini menggunakan teknik Judgment sampling karena tidak semua dapat memiliki peluang yang sama kena kriteria tertentu (Etikan et al., 2016). Penelitian Menggunakan Kuisioner Online dan melibatkan 100 mahasiswa sebagai responden. Metode yang digunakan oleh penelitian adalah SEM-PLS. Aplikasi yang digunakan untuk mengolah data adalah Smart PLS dengan model Smartpls 3.3.3.

Tabel 1

Operasionalisasi Variabel

\begin{tabular}{|c|c|c|}
\hline Variabel & Indikator & Kode \\
\hline \multirow{4}{*}{$\begin{array}{l}\text { Pendidikan } \\
\text { Kewirausahaan }\end{array}$} & Saya menikmati mata kuliah kewirausahaan & PK 1 \\
\hline & $\begin{array}{l}\text { Kewirausahaan adalah salah-satu materi saya } \\
\text { sukai. }\end{array}$ & PK 2 \\
\hline & $\begin{array}{l}\text { Saya akan berusaha untuk belajar } \\
\text { kewirausahaan }\end{array}$ & PK 3 \\
\hline & $\begin{array}{l}\text { Pembelajaran kewirausahaan mempengaruhi } \\
\text { saya untuk menjadi seorang pengusaha }\end{array}$ & PK 4 \\
\hline \multirow{3}{*}{$\begin{array}{l}\text { Dukungan } \\
\text { Finansial }\end{array}$} & $\begin{array}{l}\text { Ini akan menjadi peluang bagus jika ada } \\
\text { dukungan finansial untuk memulai bisnis baru }\end{array}$ & DF 1 \\
\hline & $\begin{array}{l}\text { Saya selalu mencari peluang dukungan } \\
\text { finansial untuk memulai bisnis potensial saya }\end{array}$ & DF 2 \\
\hline & $\begin{array}{l}\text { Selalu ada kemungkinan saya berinvestasi } \\
\text { dalam bisnis baru }\end{array}$ & DF 3 \\
\hline \multirow{3}{*}{$\begin{array}{c}\text { Sikap } \\
\text { Kewirausahaan }\end{array}$} & Saya berambisi menjadi seorang wirausaha & SK 1 \\
\hline & $\begin{array}{l}\text { Menjadi wirausahawan akan memberi saya } \\
\text { kesempatan untuk menantang diri saya sendiri }\end{array}$ & SK 2 \\
\hline & $\begin{array}{l}\text { Menjadi wirausahawan akan memberdayakan } \\
\text { kehidupan masa depan saya }\end{array}$ & SK 3 \\
\hline
\end{tabular}


Van-ni dan Wijaya: Faktor Niat Berwirausaha Pada Mahasiswa...

\begin{tabular}{|l|l|c|}
\hline & Saya tertarik dengan kewirausahaan & SK 4 \\
\hline \multirow{5}{*}{ Niat Wirausaha } & $\begin{array}{l}\text { Saya mempersiapkan diri saya untuk menjadi } \\
\text { seorang pengusaha }\end{array}$ & NK 1 \\
\cline { 2 - 3 } & $\begin{array}{l}\text { Saya akan berusaha untuk menjadi seorang } \\
\text { pengusaha }\end{array}$ & NK 2 \\
\cline { 2 - 3 } & $\begin{array}{l}\text { Saya berniat menjadi pengusaha untuk } \\
\text { menantang diri saya sendiri }\end{array}$ & NK 3 \\
\cline { 2 - 3 } & $\begin{array}{l}\text { Saya mencari peluang untuk menjadi } \\
\text { pengusaha }\end{array}$ & NK 4 \\
\cline { 2 - 3 } & $\begin{array}{l}\text { Menjadi pengusaha adalah prioritas saya } \\
\text { setelah saya lulus }\end{array}$ & NK 5 \\
\hline
\end{tabular}

Sumber : Hassan et la. 2020

\section{HASIL ANALISIS DATA}

Untuk melakukan validitas dapat dilakukan dengan Outer loading, Cross Loading, AVE dan Uji Fornell - Larcker. Berdasarkan pada hasil uji Outer Loading dan Cross Loading terhadap indikator pada variabel telah mencapai lebih dari 0,7. Pada uji Fornell-Larcker nilai rata-rata pada variabel melebihi nilai lainnya. Ketiga pengujian telah memenuhi maka indikator telah dikatakan valid (Hair et la., 2019).

Tabel 2

Hasil Uji Outer loading

\begin{tabular}{|c|c|c|c|}
\hline Variabel & Indikator & Kode & $\begin{array}{l}\text { Outer } \\
\text { loading }\end{array}$ \\
\hline \multirow{4}{*}{$\begin{array}{c}\text { Pendidikan } \\
\text { Kewirausahaan }\end{array}$} & Saya menikmati mata kuliah kewirausahaan & PK 1 & 0.834 \\
\hline & $\begin{array}{l}\text { Kewirausahaan adalah salah-satu materi saya } \\
\text { sukai. }\end{array}$ & PK 2 & 0.857 \\
\hline & $\begin{array}{l}\text { Saya akan berusaha untuk belajar } \\
\text { kewirausahaan }\end{array}$ & PK 3 & 0.855 \\
\hline & $\begin{array}{l}\text { Pembelajaran kewirausahaan mempengaruhi } \\
\text { saya untuk menjadi seorang pengusaha }\end{array}$ & PK 4 & 0.804 \\
\hline \multirow{3}{*}{$\begin{array}{c}\text { Dukungan } \\
\text { Finansial }\end{array}$} & $\begin{array}{l}\text { Ini akan menjadi peluang bagus jika ada } \\
\text { dukungan finansial untuk memulai bisnis baru }\end{array}$ & DF 1 & 0.816 \\
\hline & $\begin{array}{l}\text { Saya selalu mencari peluang dukungan } \\
\text { finansial untuk memulai bisnis potensial saya }\end{array}$ & DF 2 & 0.769 \\
\hline & $\begin{array}{l}\text { Selalu ada kemungkinan saya berinvestasi } \\
\text { dalam bisnis baru }\end{array}$ & DF 3 & 0.783 \\
\hline
\end{tabular}


Van-ni dan Wijaya: Faktor Niat Berwirausaha Pada Mahasiswa...

\begin{tabular}{|c|c|c|c|}
\hline \multirow{4}{*}{$\begin{array}{c}\text { Sikap } \\
\text { Kewirausahaan }\end{array}$} & Saya berambisi menjadi seorang wirausaha & SK 1 & 0.809 \\
\hline & $\begin{array}{l}\text { Menjadi wirausahawan akan memberi saya } \\
\text { kesempatan untuk menantang diri saya sendiri }\end{array}$ & SK 2 & 0.857 \\
\hline & $\begin{array}{l}\text { Menjadi wirausahawan akan memberdayakan } \\
\text { kehidupan masa depan saya }\end{array}$ & SK 3 & 0.855 \\
\hline & Saya tertarik dengan kewirausahaan & SK 4 & 0.804 \\
\hline \multirow{5}{*}{ Niat Wirausaha } & $\begin{array}{l}\text { Saya mempersiapkan diri saya untuk menjadi } \\
\text { seorang pengusaha }\end{array}$ & NK 1 & 0.886 \\
\hline & $\begin{array}{l}\text { Saya akan berusaha untuk menjadi seorang } \\
\text { pengusaha }\end{array}$ & NK 2 & 0.880 \\
\hline & $\begin{array}{l}\text { Saya berniat menjadi pengusaha untuk } \\
\text { menantang diri saya sendiri }\end{array}$ & NK 3 & 0.898 \\
\hline & $\begin{array}{l}\text { Saya mencari peluang untuk menjadi } \\
\text { pengusaha }\end{array}$ & NK 4 & 0.804 \\
\hline & $\begin{array}{l}\text { Menjadi pengusaha adalah prioritas saya } \\
\text { setelah saya lulus }\end{array}$ & NK 5 & 0.919 \\
\hline
\end{tabular}

Pada uji Outer Loading nilai indikator valid karena telah melebihi 0,7.

Tabel 3

Hasil Cross Loading

\begin{tabular}{|c|c|c|c|c|}
\hline Kode & $\begin{array}{c}\text { Pendidikan } \\
\text { Kewirausahaan }\end{array}$ & $\begin{array}{c}\text { Dukungan } \\
\text { Finansial }\end{array}$ & $\begin{array}{c}\text { Sikap } \\
\text { kewirausahaan }\end{array}$ & $\begin{array}{c}\text { Niat } \\
\text { kewirausahaan }\end{array}$ \\
\hline PK 1 & $\mathbf{0 . 8 3 4}$ & 0.512 & 0.445 & 0.425 \\
\hline PK 2 & $\mathbf{0 . 8 5 7}$ & 0.397 & 0.511 & 0.497 \\
\hline PK 3 & $\mathbf{0 . 8 5 5}$ & 0.394 & 0.528 & 0.498 \\
\hline PK 4 & $\mathbf{0 . 8 0 4}$ & 0.446 & 0.556 & 0.484 \\
\hline DF 1 & 0.484 & $\mathbf{0 . 8 1 6}$ & 0.519 & 0.412 \\
\hline DF 2 & 0.270 & $\mathbf{0 . 7 6 9}$ & 0.324 & 0.345 \\
\hline DF 3 & 0.428 & $\mathbf{0 . 7 8 3}$ & 0.479 & 0.442 \\
\hline SK 1 & 0.544 & 0.365 & $\mathbf{0 . 8 0 9}$ & 0.687 \\
\hline SK 2 & 0.545 & 0.531 & $\mathbf{0 . 8 6 0}$ & 0.596 \\
\hline SK 3 & 0.527 & 0.519 & $\mathbf{0 . 8 5 5}$ & 0.607 \\
\hline
\end{tabular}


Van-ni dan Wijaya: Faktor Niat Berwirausaha Pada Mahasiswa...

\begin{tabular}{|l|l|l|l|l|}
\hline \hline SK 4 & 0.354 & 0.460 & $\mathbf{0 . 7 1 4}$ & 0.522 \\
\hline NK 1 & 0.501 & 0.463 & 0.617 & $\mathbf{0 . 8 8 6}$ \\
\hline NK 2 & 0.416 & 0.378 & 0.681 & $\mathbf{0 . 8 8 0}$ \\
\hline NK 3 & 0.491 & 0.451 & 0.659 & $\mathbf{0 . 8 9 8}$ \\
\hline NK 4 & 0.531 & 0.559 & 0.638 & $\mathbf{0 . 8 0 4}$ \\
\hline NK 5 & 0.571 & 0.407 & 0.674 & $\mathbf{0 . 9 1 9}$ \\
\hline
\end{tabular}

Pada uji Cross Loading nilai indikator valid karena telah melebihi 0,7.

Tabel 4

Hasil Uji Fornell - Larcker

\begin{tabular}{|c|c|c|c|c|}
\hline & DK & NK & PK & SK \\
\hline DK & 0.790 & & & \\
\hline NK & 0.513 & 0.878 & & \\
\hline PK & 0.519 & 0.571 & 0.838 & \\
\hline SK & 0.576 & 0.746 & 0.613 & 0.812 \\
\hline
\end{tabular}

Pada uji Fornell - Larcker nilai variabel valid karena keempat variabel dari tiap variabel memiliki nilai korelasi antara variabel sendiri lebih besar dari variabel lainnya.

Tabel 5

Hasil Uji Average Variance Extracted

\begin{tabular}{|c|c|}
\hline Variabel & Average Variance Extracted \\
\hline Pendidikan Kewirausahaan & 0.624 \\
\hline Dukungan Finansial & 0.771 \\
\hline Sikap Kewirausahaan & 0.702 \\
\hline Niat Kewirausahaan & 0.659 \\
\hline
\end{tabular}

Nilai Average Variance Extracted (AVE) memiliki nilai yang melebihi 0.50 maka indikator dinyatakan valid.

Tabel 6

Hasil Uji Reliabilitas

\begin{tabular}{|c|c|c|}
\hline Variabel & Cronbach's Alpha & Composite Reliability \\
\hline Pendidikan Kewirausahaan & 0.859 & 0.904 \\
\hline Dukungan Finansial & 0.705 & 0.833 \\
\hline Sikap Kewirausahaan & 0.826 & 0.885 \\
\hline
\end{tabular}


0.925

0.944

Nilai Cronbach's Alpha memiliki nilai mencapai atau lebih dari 0,70. Composite reliability akan terkonfirmasi bila mencapai 0.70 .

Tabel 7

Hasil Uji R-Square dan Q-Square

\begin{tabular}{|c|c|c|}
\hline Variabel & R-Square & Q-Square \\
\hline Sikap Kewirausahaan & 0.467 & 0,297 \\
\hline Niat Kewirausahaan & 0.556 & 0,421 \\
\hline
\end{tabular}

Pada Uji R-square Pengaruh pendidikan kewirausahaan dan dukungan finansial kepada sikap kewirausahaan Sikap kewirausahaan menunjukan nilai 0,467 menandakan dampak yang lemah. Pendidikan kewirausahaan, dukungan finansial dan sikap kewirausahaan adalah niat kewirausahaan adalah 0,556 yaitu moderate. Uji Q-square sikap kewirausahaan menunjukan nilai sebesar 0,297 menandakan bahwa Pendidikan kewirausahaan dan Dukungan finansial memiliki prediksi yang besar terhadap sikap kewirausahaan. Untuk Niat kewirausahaan dengan nilai 0,421, menandakan bahwa Pendidikan kewirausahaan, dukungan dan sikap kewirausahaan memiliki nilai prediksi yang besar pula kepada niat kewirausahaan. Uji Goodness of fit yang dihasilkan adalah 0.776. Nilai tersebut sudah mencapai lebih dari 0,36. Maka dapat disimpulkan kecocokan model sudah baik (Hair et la., 2019).

Tabel 8

Hasil Uji f-Square

\begin{tabular}{|c|c|c|c|c|}
\hline Variabel & DK & NK & PK & SK \\
\hline DK & & & & 0.170 \\
\hline NK & & & & \\
\hline PK & & & & 0.253 \\
\hline SK & & 1.254 & & \\
\hline
\end{tabular}

Model Dukungan finansial kepada sikap kewirausahaan serta pendirikan kewirausahaan kepada sikap kewirausahaan masuk dalam kategori moderate sedangkan sikap kewirausahaan kepada niat kewirausahaan kuat.

Tabel 9

Hasil Kesimpulan Pengujian Hipotesisi

\begin{tabular}{|c|c|c|c|c|}
\hline $\begin{array}{c}\text { Kode } \\
\text { Hipotesis }\end{array}$ & Hipotesis & $\begin{array}{c}\text { Original } \\
\text { Sample }\end{array}$ & T-Statistics & P-Values \\
\hline H1 & $\begin{array}{c}\text { Pendidikan Kewirausahaan } \rightarrow \\
\text { Sikap Kewirausahaan }\end{array}$ & 0,430 & 4,314 & 0,000 \\
\hline
\end{tabular}




\begin{tabular}{|c|c|c|c|c|}
\hline H2 & $\begin{array}{c}\text { Dukungan finansial } \rightarrow \\
\text { Sikap Kewirausahaan }\end{array}$ & 0.353 & 3,714 & 0,000 \\
\hline H3 & $\begin{array}{c}\text { Sikap Kewirausahaan } \rightarrow \text { Niat } \\
\text { Kewirausahaan }\end{array}$ & 0,746 & 13,862 & 0,000 \\
\hline
\end{tabular}

Dalam Uji Hipotesis Pertama, Hasil pengujian variabel pendidikan kepada niat kewirausahaan. Nilai Original Sampel yang dihasilkan berupa nilai positif. Nilai T-statistik yang dihasilkan sebesar 4,314 dan P-value 0,000. Nilai T-statistik dan P-value tersebut sudah sudah melebihi 1,96 dan kurang dari 0,05. Dengan demikian hipotesis diterima dan dapat disimpulkan bahwa variabel Pendidikan kewirausahaan berpengaruh positif dan signifikan terhadap sikap kewirausahaan dan niat kewirausahaan

Uji Hipotesis Kedua, Nilai Original Sample yang dihasilkan berupa nilai positif. Nilai T-statistik yang dihasilkan sebesar 3,714 dan P-value 0,000. Dengan demikian dapat disimpulkan bahwa Dukungan Finansial berpengaruh positif dan signifikan terhadap sikap kewirausahaan dan niat kewirausahaan.

Hipotesis Ketiga, nilai Original Sample berupa nilai positif. t-statistik yang dihasilkan sebesar 13,862 dan P-value 0,000. Maka dengan demikian hipotesis ketiga dapat diterima. Dengan demikian disimpulkan bahwa variabel sikap kewirausahaan berpengaruh positif dan signifikan terhadap niat kewirausahaan.

\section{DISKUSI}

Pada hipotesis pertama memiliki pengaruh positif signifikan antara pendidikan kewirausahaan kewirausahaan dan sikap kewirausahaan untuk berwirausahaan mahasiswa perguruan tinggi swasta di Jakarta barat. Berkembangnya pendidikan tentang wirausahaan merupakan bagian yang penting. Sebab pendidikan yang baik dapat memberikan dorongan kepada individu untuk usaha sendiri. Pembelajaran terkait kewirausahaan memicu pengembangan sikap kewirausahaan (Arranz et la., 2019)

Pada hipotesis kedua antara dukungan finansial dan sikap kewirausahaan pada niat kewirausahaan. Hasil pengujian hipotesis menunjukan bahwa adanya pengaruh positif dan signifikan maka dukungan finansial berpengaruh positif dan signifikan kepada sikap kewirausahaan untuk berwirausahaan oleh mahasiswa perguruan tinggi swasta di Jakarta barat. Mereka yang bertekad mencari potensi untuk mengembangkan usahanya. Sebab sumber keuangan adalah sebuah kebutuhan dari pembentuk dan pengembangan sebuah usaha. (Bellavitis et al., 2017).

Pada hipotesis ketiga pengaruh positif antara sikap kewirausahan dan niat kewirausahaan mahasiswa perguruan tinggi swasta di Jakarta barat. Pada penelitian Potishuk dan Kratzer (2017) Sikap kewirausahaan merupakan penggerak, pendorong pada intensi individu untuk berwirausaha. Sikap tersebut tumbuh dari diri individu. Sikap merupakan bagian dari perilaku. Berawal dari rasa ketertarikan Mereka yang memiliki ambisi dari individu untuk memulai usaha baru.

\section{KESIMPULAN}

Pada penelitian, Pendidikan terkait kewirausahaan memiliki pengaruh yang signifikan. Pihak akademis dapat meningkatkan kualitas pendidikan akan kewirausahaan agar menumbuhkan benih-benih wirausaha pada calon wirausahawan. Pada calon wirausahaan dukungan finansial dapat menjadikan pertimbangan sumber pendanaan yang dapat 
dipertimbangkan untuk membangun usahanya salah satu melalui platform digital. Pada pihak akademis, Peneliti ini hanya meneliti variabel Pendidikan Kewirausahaan, Dukungan Finansial, Sikap kewirausahaan dan Niat Kewirausahaan. Untuk kedepannya penelitian terkait variabel lain dapat menjadi pertimbangan serta memperluas wilayah jangkauan penelitian agar penelitian dapat mencangkup penelitian yang lebih dalam dari penelitian sebelumnnya

\section{DAFTAR PUSTAKA}

Acs, Z.J., Estrin, S., Mickiewicz, T. dan Szerb, L. (2018) "Entrepreneurship, institutional economics and economic growth: an ecosystem perspective". Small Business Economics 51(2): 501-514. https://doi.org/10.1007/s11187-018-0013-9

Arranz, N., Arroyabe, M. F., dan Fdez. de Arroyabe, J. C. (2019) "Entrepreneurial intention and obstacles of undergraduate students: the case of the universities of Andalusia". Studies in Higher Education, 2011-2024. https://doi.org/10.1080/03075079.2018.1486812

Bellavitis, C., Filatotchev, I., Kamuriwo, D. S., dan Vanacker, T. (2017) "Entrepreneurial finance: new frontiers of research and practice". Venture Capital, 19(1-2): 1-16. https://doi.org/10.1080/13691066.2016.1259733

Botsaris, C., dan Vamvaka, V. (2016) "Attitude Toward Entrepreneurship: Structure, Prediction from Behavioral Beliefs, and Relation to Entrepreneurial Intention". Journal of the Knowledge Economy 7(2): 433-460. https://doi.org/10.1007/s13132-014-0227-2

BPS. (2020). BPS: 270,20 juta Penduduk Indonesia Hasil SP2020. Diakses dari : https://www.bps.go.id/news/2021/01/21/405/bps--270-20-juta-penduduk-indonesiahasil-sp2020.html Pada 23/03/2021.

Do, B.R. dan Dadvari, A. (2017) "The influence of the dark triad on the relationship between entrepreneurial attitude orientation and entrepreneurial intention: a study among students in Taiwan university". Asia Pacific Management Review 22(4): 185-191. https://doi.org/10.1016/j.apmrv.2017.07.011

Etikan, I., Musa, S. A., dan Alkassim, R. S. (2016) "Comparison of convenience sampling and purposive sampling". American journal of theoretical and applied statistics, 5(1): 1-4.

Hair, J.F., Black, W.C., Babin, B.J. \& Anderson, R.E. (2019). Multivariate Data Analysis: A Global Perspective. Hampshire: Cengage Learning EMEA.

Hansfel, L., dan Puspitowati, I. (2020) "Pengaruh Attitude, Subjective Norm dan Perceived Behavior Control terhadap Entrepreneurial Intention”. Jurnal Manajerial dan Kewirausahaan 2(4): 985-993.

Hassan, H., Sade, A. B., dan Rahman, M. S. (2020) "Shaping entrepreneurial intention among youngsters in Malaysia”. Journal of Humanities and Applied Social Sciences, 2(3): 235251.

Hisrich, R. D., Peters, M.P. dan Shepherd D. A. (2017) Entrepreneurship. New York: Mc. Graw-Hill Education.

Hsiung, T. (2018) "Satisfaction with entrepreneurial education and entrepreneurial intention: The moderating role of internal locus of control". International Journal of Education and Research 6(4): 139-146.

Kim, M. dan Park, M.J. (2019) "Entrepreneurial education program motivations in shaping engineering students' entrepreneurial intention: The mediating effect of assimilation and accommodation". Journal of Entrepreneurship in Emerging Economies 11(30): 328-350. https://doi.org/10.1108/JEEE-08-2018-0082 
Masango, S.G. dan Lassalle, P. (2020) "What entrepreneurs do? Entrepreneurial action guided by entrepreneurial opportunities and entrepreneurial learning in early internationalising firms". International Marketing Review 37(6): 1083-1119. https://doi.org/10.1108/IMR10-2018-0273

Monica, D., dan Wijaya, A. (2021) "Pengaruh Close Environmental Factors Terhadap Entrepreneurial Intentions Dimediasi Oleh Individual Entrepreneurial Orientation". Jurnal Manajerial dan Kewirausahaan, 3(2): 335-344.

Potishuk, V., dan Kratzer, J. (2017) "Factors affecting entrepreneurial intentions and entrepreneurial attitudes in higher education". Journal of Entrepreneurship Education, 20(1): 25-44.

Raza, A., Muffatto, M. dan Saeed, S. (2018) "The influence of formal institutions on the relationship between entrepreneurial readiness and entrepreneurial behaviour: A crosscountry analysis". Journal of Small Business and Enterprise Development, 26(1): 133157. https://doi.org/10.1108/JSBED-01-2018-0014

Thompson, E. R. (2009) "Individual entrepreneurial intent: construct clarification and development of an internationally reliable metric. Entrepreneurship". Theory and Practice 33(3): 669-694. https://doi.org/10.1111\%2Fj.1540-6520.2009.00321.x 